\title{
CORRESPONDENCE
}

\section{BREEDING AND MAINTENANCE OF SLEDGE DOGS}

I should like to question a number of Mr Taylor's statements in his article "The breeding and maintenance of sledge dogs" (Polar Record, Vol. 9, No. 56, 1957). Like him I have worked with F.I.D.S. sledge dogs and, in addition, have spent a winter with the West Greenlanders and two years with the British North Greenland Expedition where we often sledged with the Danish Sledge Patrol and various Danish and Norwegian trappers.

1. Mr Taylor states that "there is considerable agreement that the husky ...is descended in the main from the wolf". I suggest that there is also considerable agreement that the contrary is the case, and that dogs are not descended from wolves at all.

2. I feel he gives a wrong impression of the weight of huskies when he states "... the weight of northern huskies is about $80 \mathrm{lb}$.". In fact it varies considerably from district to district between about 60 and $100 \mathrm{lb}$.

3. The last sentence of "Changes in the F.I.D.S. dogs" is a misquotation. Alan Reece states that the dogs the Norwegian-British-Swedish Antarctic Expedition obtained from Spitsbergen were of Canadian origin, not Greenlandic. He also says that the West Greenland and F.I.D.S. dogs were much the same weight, which seems surprising, but was probably due to the F.I.D.S. dogs in question being of poor quality.

4. Although the "health of dogs at base" may have been "excellent" in general (p. 432), Mr Taylor does not mention the large percentage of accidental puppy deaths, namely, one-third of the puppies of the ten litters for which he gives figures in his official report. I suggest that this may have been due to the type of indoor kennel at Hope Bay which, contrary to recommended practice, has no outdoor opening for the bitch. However, the whole question of puppy deaths is very debatable.

5. Sledging methods. "Whips are rarely carried", Mr Taylor says. No wonder "some leaders were poor and inexperienced" and no wonder Mr Taylor had to have someone ski-ing ahead of his team for most of his only long sledge trip. I have just spent one winter with F.I.D.S. and the use of whips for driving sledge dogs is becoming common again. I am convinced that it is far easier to train a new leader, or a newly formed team or a young dog with the aid of a whip than without one, and I believe that recent practices in F.I.D.S. have proved this conclusively. There is no need to use a whip cruelly, its main use is for steering; once a leader and/or team is well trained, the whip is hardly necessary. Bingham and Croft both make similar statements. Admittedly, the type of whip recently supplied to F.I.D.S. was not easy to handle, but this matter is being seen to.

6. I presume that there was a reason for having teams which "could be allocated to anybody", but in my experience the most efficient 'crack' team 
is produced by being driven by the same man all the time, and this agrees with Base $E$ practice in 1946-49, when, I believe, a particularly high standard of British dog-driving was reached. There is no reason why each team should not be "of nearly equal strength".

7. The age to start training puppies. Various people have recommended different ages, between 6 and 12 months, due, I suspect, to confusion about what "training" means. Training dogs to obey orders and run in their correct place, i.e. mental training, should be started in my opinion at six months. This agrees with Greenlanders' techniques, which result in a high standard of obedience. The physical training needs careful control; in order to build up the dog's pulling muscles and general fitness without impeding his normal growth, he should not be over-exercised to begin with. I suggest an hour's run two or three times a week in the seventh month, two hours in the eighth month and so on, working up to short proper journeys round about eleven and twelve months. This is definitely less exercise than the usual Greenlander practice and in that respect may partially account for the weight difference referred to in (2) above.

8. "Dogs suffered from boredom while on the spans." If dogs are out sledging for three-quarters of the year as they should be, I cannot believe that their time on the span will weaken their mental stamina. However, I do think it would be a good thing to put a dog team into a pen occasionally at a base (with the driver standing by!) for another reason: to let the dogs establish internal discipline, the order of seniority from boss dog downwards. Once this is firmly established, dog fights are far less frequent and the team in general is far more controllable. I have sledged hundreds of miles with the Danish N.E. Greenland Sledge Patrol, who always keep theirs loose, and I noticed no difference in mental stamina of the dogs.

9. It is very difficult to pin down a dog's "final" weight. It varies with the dog's age (from one year onwards), the season of the year, the quantity and quality of his food, the exercise he is, or has been, taking, whether there are bitches on heat nearby, the condition of his coat, whether he has any moisture in his coat when he is weighed, etc. Also a dog's weight/age graph flattens out between 7 and 18 months so that it is difficult to conclude anything definite there. However, in my experience, dogs reach full weight much earlier than Mr Taylor suggests, namely, around 9 months, and $I$ have figures to support this statement. In fact, the dogs quoted in his Fig. 1 had a final weight of nearer $89 \mathrm{lb}$. than $95 \mathrm{lb}$., and hence it proves my point.

10. Colour. The F.I.D.S. present dominating strain of black-and-white dogs is unusual in my experience (65 per cent of the dogs at Base $W$ are that colour). Such colours were in a minority in Jakobshavn in 1951, north east Greenland 1952-54 and Spitsbergen in 1956; the dominating colours there were a type of brindle or dirty browny-grey, with all-red and all-black running second place.

11. Mr Taylor states that his dogs suffered boredom on the Iarsen Ice Shelf, and he had to have someone ski-ing ahead most of the time. The recent magnificent air-supported journeys of the New Zealanders in the Antarctic 
prove that dogs will never be bored if they are really well fed-a fact that any Arctic trapper knows. However, on the ration that Mr Taylor's dogs had, their performance still sounds comparatively poor, which I respectfully suggest was due to the inadequacy of the lead dogs and wrong methods of training and driving.

To sum up my personal views:

(a) Dogs should begin to be trained at 6 months.

(b) One team should always be driven by the same man.

(c) The whip should be used, especially for training.

(d) Teams should be in the field for three-quarters of the year. (Glen describes how his dogs on his 1935-36 expedition were used from August to August).

(e) Every team should have a properly trained leader dog who is not used to following a man or another team.

(f) Every team should have a reserve leader.

I believe that any "psychology" involved in dog driving is in the general training of the teams and the relationship between the driver and his dogs, and not in Mr Taylor's "three grades of sledge dogs". So far as the intelligence of a husky is concerned, terms are relative; I think that most huskies are stupid and it is probably just as well. The tiny quantity of sense needed by a leader to obey about four very simple orders surely hardly counts as intelligence. Most domestic dogs could learn them far quicker than a husky does.

12. I agree with Mr Taylor that mechanical and dog transport are each superior to the other in different conditions, though the validity of some of the figures in his Tables 2 and 3 is open to question. To take one example only, the term "payload" normally refers to the useful load a vehicle can carry not including its own fuel. In that case the average payload of a dog team should be about $250 \mathrm{lb}$. and that of the towed sledge of a Weasel "nil" (for full range). The figure for the Weasel is correct as fuel is not usually carried in the vehicle itself.

ANGUS ERSKINE

10 MELCOMBE COURT,

DORSET SQUARE,

LONDON

4 September 1958 